\title{
Temporal and spatial variability in recruitment of a temperate, seagrass-associated fish is largely determined by physical processes in the pre- and post-settlement phases
}

\author{
Gregory P. Jenkins ${ }^{1, *}$, Kerry P. Black ${ }^{2}$, Melissa J. Wheatley ${ }^{3}$, David N. Hatton ${ }^{1}$ \\ ${ }^{1}$ Marine and Freshwater Resources Institute and Department of Zoology, University of Melbourne, PO Box 138, Queenscliff, \\ Victoria 3225, Australia \\ ${ }^{2}$ National Institute for Water and Atmospheric Research Ltd, and Department of Earth Sciences, University of Waikato, \\ PO Box 11-115, Hamilton, New Zealand \\ ${ }^{3}$ Department of Ecology and Evolutionary Biology, Monash University, Wellington Road, Clayton, Victoria 3168, Australia
}

\begin{abstract}
Post-settlement King George whiting Sillaginodes punctata were sampled every 3 to $4 \mathrm{~d}$ from mid-September to the end of October 1993, at 3 seagrass sites within Port Phillip Bay, Australia. The site closest to the entrance (St Leonards) showed short-lived pulses of recruits in low numbers. The site of intermediate distance into the bay (Grassy Point) showed a similar pattern; however, in this case there was a marked accumulation of recruits over time. In contrast, recruitment was low at the site furthest into the bay (Grand Scenic), and the pattern was unlike the other sites. We simulated the transport of S. punctata larvae into Port Phillip Bay over this perıod using 2- and 3-dimensional hydrodynamic and dispersal models. A high proportion (two-thirds) of the variation in recruitment at St Leonards and Grassy Point could be explained by 2 factors: the predicted arrival of larvae based on passive transport by currents, and disturbance of individual seagrass sites by wave action. Patterns of recruitment at Grand Scenic, however, a site that was at the limit of larval dispersal into the bay, were unrelated to model predictions or environmental variables. The daily pattern of arrival of larvae to Port Phillip Bay was estimated from recruits using a transition in otolith microstructure. The daily pattern of arrival estimated for individuals collected from St Leonards was significantly correlated with westerly wind stress and residual sea level, and negatively correlated with barometric pressure. It appears that strong westerly winds and low barometric pressure associated with the passage of weather systems lead to positive sea level anomalies in Port Phillip Bay, and the passive transport of larvae into the bay. Interannual variability in weather patterns would be expected to lead to interannual variability in larval supply to Port Phillip Bay.
\end{abstract}

KEY WORDS: Recruitment variability Physical processes - Juvenile fish Seagrass habitat

\section{INTRODUCTION}

Most sedentary or demersal marine animals have a dispersive larval phase. Recruitment of young can be highly variable, and this variability may have a longterm influence on the demography of a population (Hughes 1990, Raimondi 1990, Doherty \& Fowler 1994). One potential source of recruitment variability is variation in larval supply, and links between larval supply and recruitment have been demonstrated for some

•E-mall: g.jenkins@msl.oz.au species (Gaines et al. 1985, Hurlbut 1992, Milicich et al. 1992). It is likely that a major influence on larval supply will be the coastal oceanography responsible for transport of larvae (Underwood \& Fairweather 1989).

A strong influence of coastal oceanography on larval supply has been demonstrated for some invertebrate species (Goodrich et al. 1989, Farrell et al. 1991, Little \& Epifanio 1991). The linkage between coastal oceanography and larval supply of demersal fishes is less clear. Large-scale recruitment of a temperate reef fish estimated from visual transects and population age struc- 
ture was found to be strongly influenced by large-scale oceanography (Cowen 1985). The linkage between oceanographic processes and larval supply of tropical reef fishes measured by light-traps (Milicich 1994) and channel nets (Thorrold et al. 1994) was variable between taxa, years, habitats and other factors. Thorrold et al. (1994) suggested that fishes are less likely to be influenced primarily by physical transport patterns because they have relatively well-developed swimming abilities and complex behaviours.

Post-settlement losses have also been found to be a potent force influencing the recruitment of benthic fishes (Shulman \& Ogden 1987, Sale \& Ferrell 1988, Booth 1991). The causes of post-settlement losses are poorly understood, but may include factors such as food resources, competitors, shelter, and predation (Shulman \& Ogden 1987), with most evidence related to predation (Hixon \& Beets 1993) Some studies have linked post-settlement mortality to habitat complexity (Connell \& Jones 1991, Levin 1994). A further factor which has received little consideration is disturbance, either physical or biological (Jones 1991). Local re cruitment rates may be influenced by movement as well as mortality (Sogard 1989), although local movements will not necessarily affect recruitment at Iarger scales.

King George whiting Sillaginodes punctata is an important commercial fish species in southern Australia. Post-larvae, defined as newly settled specimens prior to scale formation (Bruce 1995), and juveniles up to approximately 3 yr of age, are generally associated with seagrass habitats in sheltered gulfs, bays and inlets (Jones 1980, Hutchins \& Swainston 1986). With the onset of reproductive maturity at the age of 3 to $4 \mathrm{yr}$, individuals generally move out of bays into coastal waters (Jones 1980). In central Victoria, settlement occurs from August to November, the southern spring (Robertson 1977, Jessop 1988, Jenkins \& May 1994). The larval duration is long ( 100 to $170 \mathrm{~d}$ ), with spawning estimated to occur from approximately April to July (Jenkins \& May 1994). Settlement-stage individuals range from approximately 15 to $20 \mathrm{~mm}$ in length (Jenkins \& May 1994). Evidence suggests that spawning of $S$. punctata occurs offshore from bay and inlet habitats. In South Australia, pre-settlement larvae were collected in sheltered gulfs; however, smaller larvae were in nearshore coastal waters (Bruce 1989). The only known spawning area is near an offshore island in South Australia (Bruce pers. comm.). In Port Phillip Bay, no eggs or early-stage larvae of $S$. punctata have been collected (Jenkins 1986, F. Neira pers. comm.), although we regularly collect late-stage larvae (Hamer \& Jenkins in press). Furthermore, although a substantial fishery occurs in Port Phillip Bay, no reproductively mature fish are caught.
Jenkins \& Black (1994) showed a strong correlation between temporal patterns of settlement of Sillaginodes punctata, estimated from otolith microincrements, and the predictions of a numerical hydrodynamic model that simulated transport of neutrally buoyant particles to the coastal habitats. A complex interaction of oceanographic and climatic factors appeared to lead to a net transport of larvae into the bay on a 10 to $14 \mathrm{~d}$ cycle (Jenkins \& Black 1994). These results considered temporal variability only and were related to a relatively small area of juvenile habitat. The aim of the present study is to examine the influence of coastal hydrodynamics on recruitment on a short-term temporal scale and also on a broader spatial scale within Port Phillip Bay. Recruitment at sites is estimated from high frequency sampling. A transition in otolith microstructure is used to hindcast the pattern of arrival of larvae to Port Phillip Bay. We compare patterns of arrival at Port Phillip Bay and recruitment to sites with predictions of both 2-and 3-dimensional hydrodynamic dispersal models. We also use a numerical model to predict the effect of waves at recruitment sites. For the first time we identify climatic and hydrodynamic factors influencing temporal and spatial variability in the recruitment of this species. We show that physical processes strongly affect variability in recruitment in both the pre-and post-settlement phases.

\section{METHODS}

Study area. Port Phillip Bay is a large, semi-enclosed, predominantly tidal embayment linked to the ocean of the Bass Strait by a narrow entrance (Fig. 1). The hydrodynamics are characterised by an entrance region where fast ( $3 \mathrm{~m} \mathrm{~s}^{-1}$ ) ebb and flood jets dominate the circulation, a large flood-tidal delta, known as the Sands region, where strong currents occur in the major channels, and an 'inner' zone where tidal currents are weak (Black et al. 1993). On the western side of Port Phillip Bay, tidal currents drop to below $0.1 \mathrm{~m} \mathrm{~s}^{-1}$ at about the entrance to the Geelong Arm. Tidal range inside the bay is less than $1 \mathrm{~m}$.

Seagrass around the Bellarine Peninsula area of Port Phillip Bay (Fig. 1) consists generally of narrow $(20 \mathrm{~m}$ wide) bands of the subtidal seagrass Heterozostera tasmanica running parallel to the shoreline. In the Geelong Arm, however, seagrass beds become more widespread due to protection from the predominant south westerly wind experienced in the region. This pattern is reflected by the distribution of sediment grain size, which becomes progressively finer from the Sands region around the Bellarine Peninsula and into the Geelong Arm (Anonymous 1973).

Field sampling. Sampling was conducted at 3 locations (St Leonards, Grassy Point and Grand Scenic) on 


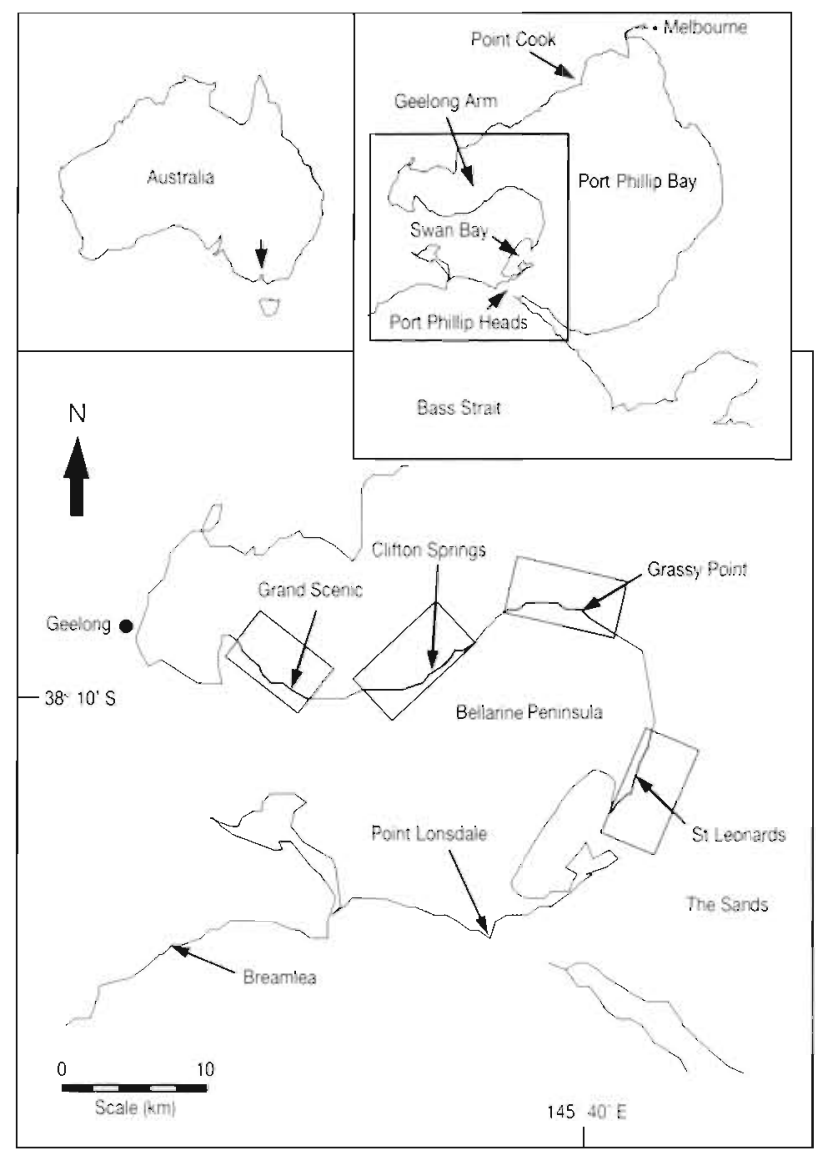

Fig 1. Location of sampling sites around the Bellarine Penınsula region of Port Phillup Bay, Victorla, from which postlarval Sillaginodes punctata worc collected in 1993. Stuppled areas represent model 'boxes' where particle numbers wore recorded during simulations. Insets: Location of the Bellarine Peninsula in Port Philip Bay and location of Port Phillip Bay on the Australian coast

the Bellarine Peninsula (Fig. 1). At each location Heterozostera tasmanica beds, averaging approximately $0.5 \mathrm{~m}$ below Mean Low Water Spring (MLWS), were sampled. Sampling was conducted at approximate 3 to 4 d intervals from September 2 to October 29, 1993. Samples were collected $2 \mathrm{~h}$ each side of low tide and the order of sampling sites was varied amongst dates.

Post-settlement Sillaginodes punctata were sampled with a seine net of $10 \mathrm{~m}$ length, $3 \mathrm{~m}$ drop, and a mesh of approximately $1 \mathrm{~mm}^{2}$ (non-stretch) The weight of the footrope was approximately $3.5 \mathrm{~kg}$. Two $10 \mathrm{~m}$ ropes were attached to each end of the seine. Four replicate hauls, haphazardly placed and non-overlapping, were made at each site. Hauls were made by 2 people walking out to the appropriate depth, one person walking $10 \mathrm{~m}$ further out, setting the net parallel to shore and returning to the position of the second person where the net was then hauled into a bucket. Retrieval of the net took approximately $30 \mathrm{~s}$. The net was then carried back to shore where post-settlement $S$. punctata were sorted, anaesthetised in benzocaine, and preserved in $95 \%$ ethanol. A beach seine net has been shown to be an efficient sampler of post-settlement S. punctata in seagrass habitat (Connolly 1994).

Laboratory analysis. For sampling dates where more than 20 specimens were collected, a haphazard subsample of 20 to 30 individuals was taken across replicates for analysis. The standard length (SL; tip of the snout to the tip of the caudal peduncle) of specimens was measured under a dissecting microscope fitted with an ocular micrometer Methods for preparation and analysis of otolith microincrements are given in Jenkins \& May (1994). Daily periodicity of increment formation in Sillaginodes punctata otoliths has been verified (Jenkins \& May 1994). A transition in otolith microstructure, where increments show a marked increase in width, was apparent near the otolith edge (Jenkins \& May 1994). Post-transition increments were counted on lapilli from the point where increments showed a marked increase in width to the otolith edge (Jenkins \& May 1994) The number of post-transition increments was assumed to approximate the number of days since the arrival of an individual to Port Phillip Bay (Jenkins \& Black 1994, Jenkins \& May 1994)

Modelling. The circulation was depicted using a Eulerian, numerical, hydrodynamic model, '3 dimensional dynamics (3DD)', of Port Phillip Bay and the adjacent ocean of Bass Strait (Black et al. 1993, Black 1995). Both 2- and 3-dimensional models were available (Black et al. 1993 and references therein). The model incorporated the important processes identified by analysis of current and sea level measurements. The 3-dimensional model incorporates full specification of the currents through the water column, while the 2-dimensional model applies an empirical relationship for the vertical variation in current strength. The 3-dimensional model would be expected to give a more realistic prediction of flows in an enclosed bay with complex circulation (Black et al. 1993). A. high level of calibration against 3 years of field data has been achieved (Black et al. 1993) The open boundary was placed $20 \mathrm{~km}$ south of the entrance in Bass Strait (Fig. 1). Tidal oscillations were obtained from records based on previous measurements at the model boundary in Bass Strait (Black et al. 1993). Low frequency (non-tidal) oscillations due to factors such as wind, barometric pressure and coastal-trapped waves were represented by using sea levels recorded at Point Lonsdale (Fig 1) during the settlement period. Tidal analyses (Foreman 1977) were applied to remove the tidal component of sea level oscillations at Point Lonsdale. Wind measurements over the settlement period, recorded at Point Cook (Fig. 1), were incorporated. 
Dispersal of neutrally buoyant particles was simulated in a Lagrangian particle model, 'Pollution-dispersal 3 Dimensional Dynamics (POL3DD)' (Black et al. 1990 , Black 1996). The hydrodynamic model solved the fluid flow equations to produce a $1.5 \mathrm{~km}$-square grid of currents for calculation of the advection in the dispersal model, while diffusion was modelled as a Monte Carlo random walk (Black et al. 1990). The horizontal diffusion coefficient was taken such that the random step was $40 \%$ of the advection distance along the flow direction and $10 \%$ laterally. The larger value attempts to represent the shear in the boundary layers (Black et al. 1990). Sensitivity testing of the eddy diffusivity showed that the general conclusions were not strongly affected by the choice of the eddy diffusivity coefficient. The advection of particles moving with the currents was more important.

The release point for particles was at Breamlea, approximately $20 \mathrm{~km}$ west of Port Phillip Heads, along a line extending $10 \mathrm{~km}$ from the coast (Fig. 1). This release point was chosen because most larvae would be expected to have been transported from the west (Jenkins \& Black 1994). Sixteen particles were released every $2 \mathrm{~h}$ from the start of the model run. Continuous release was chosen because spawning has been shown to be relatively continuous (Jenkins \& May 1994), and previous simulations using continuous release have shown a good correlation with recruitment at a site in Port Phillip Bay (Jenkins \& Black 1994). Simulations began at 00:00 h on 1 September 1993. Results were recorded spatially as the number of particles in cells (each $1.5 \mathrm{~km}$ square) over the model grid (scaled as a percentage of the largest number of particles recorded in any cell on the grid), and temporally were recorded in 'boxes' (incorporating a group of cells) superimposed on the model grid (Fig. 1). One 'box' was located adjacent to each study site with an additional box located at Clifton Springs within the Geelong Arm (Fig. 1). Numbers of particles in boxes were recorded at 30 min intervals and the data is presented as the average number per $30 \mathrm{~min}$ recorded each day from a single run of the model.

Wave model. Wave heights were hindcast with a pseudo-steady wave generation model for intertidal, enclosed estuaries of complex shape. 'Wave Generation 3 Dimensional Dispersal (WGEN3DD)' (Black \& Rosenberg 1992, Black et al. 1996). The model adapts the JONSWAP fetch-limited equations (Hasselman et al. 1973, 1976) by additionally incorporating semiempirical relationships to simulate wave shoaling, depth-limited breaking and bed frictional resistance. In estuaries with changing plan shape, the effective fetch is calculated by adopting a cosine weighting function about the mean wind direction, as described in the Shore Protection Manual (1984). The model has been tested for different environments with varying depths, current strengths, plan shapes and morphology (Black et al. 1996). In Port Phillip Bay, the model was confirmed by comparisons of hindcasts with measured orbital currents under locally generated waves (Black et al. 1996) For the present analyses, the wave heights offshore of the seagrass beds (beyond the surf zone) were hindcast in order to estimate total wave energy arriving at the sampling sites. Bed friction was found to have minimal influence for the short period waves ( 3 to $5 \mathrm{~s}$ significant period) in deep and intermediate depths (8 to $25 \mathrm{~m}$ depths in open waters).

Data analysis. Time series of post-larval abundance, model outputs, and physical variables were compared using correlation. Correlations on data at a daily level of resolution were examined for lags of up to $3 \mathrm{~d}$. Before correlations were performed, we addressed the problem of autocorrelation within individual time series. Where significant autocorrelation was apparent, we determined the 'effective' sample size $\left(n^{*}\right)$ using the method outlined by Bayley \& Hammersley (1946) and applied to physical oceanographic problems by Garrett \& Petrie (1981) and Garrett \& Toulany (1981). This method has the advantage of preserving low frequency variation in the time series. Where the particle time series from the model showed a trend of increasing numbers and variance over time not apparent in the recruitment time series, the particle time series was first log transformed, and then the residuals were calculated from a linear regression of particle abundance against time. The time series of residuals was used in cross-correlation analyses. This transform, which we refer to as $\log /$ trend, produced a relatively stationary time series (Jenkins \& Black 1994). Where trend was apparent in a time-series, an alternative transform, differencing, was also used (Box \& Jenkins 1986). This transform involved subtracting from each point in the time series the value of the previous point (Wilkinson et al. 1992). This transform will make series with nonlinear trend stationary, but at the same time will tend to eliminate low frequency variation. Thus, comparisons involving time series that have been differenced will mainly provide information on high frequency variation. When model time series were compared to recruitment data, a single-tail test was used because we placed no significance on a negative relationship.

\section{RESULTS}

\section{Recruitment}

The pattern of abundance of recruits over the sampling period varied widely amongst sites (Fig. 2). At the St Leonards site, recruits occurred in pulses, cen- 


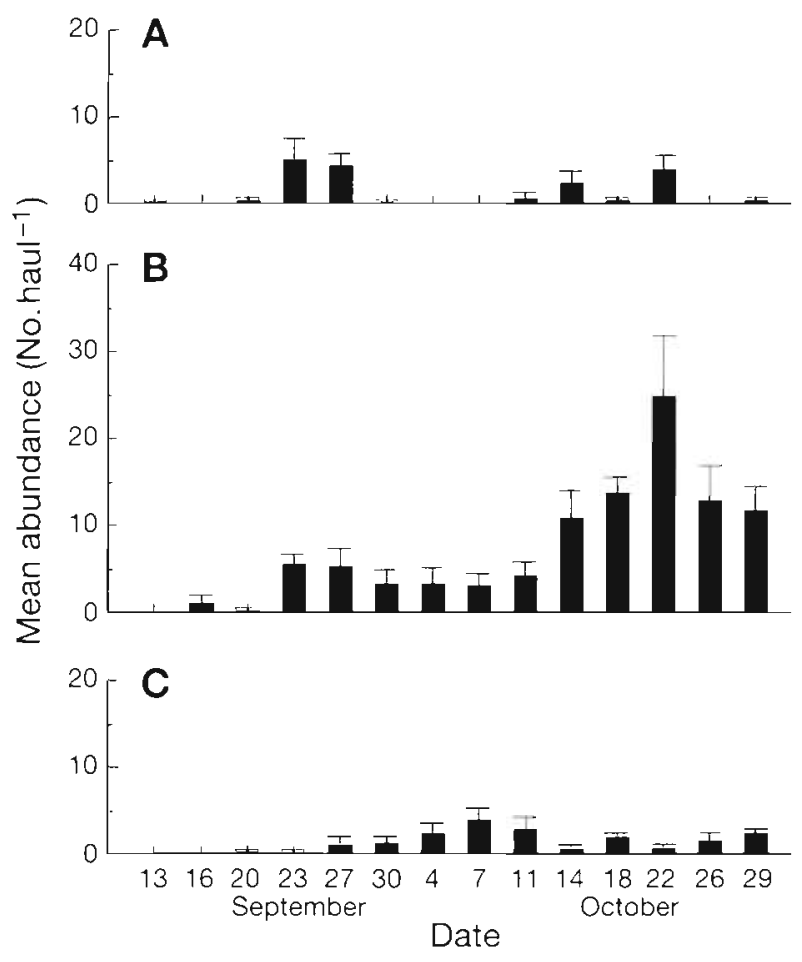

Fig. 2. Sillaginodes punctata. Mean abundance of post-larvae collected every 3 to $4 \mathrm{~d}$ in 1993 at sites around the Bellarne Peninsula. (A) St Leonards, (B) Grassy Point. (C) Grand Scenic. Error bars are standard error

tred around 23 September, and 14 and 22 October, each of which declined rapidly a few days after they appeared (Fig. 2A). Abundances at the Grassy Point site showed pulsing similar to the pattern at St Leonards, except that there was an accumulation of post-larvae over time, particularly in October (Fig. 2B). There was a significant correlation between abundances at St Leonards and the differenced $(\mathrm{n}=15, \mathrm{r}=$ $0.573, \mathrm{p}<0.05)$ and $\log /$ trend $(\mathrm{n}=15, \mathrm{r}=0.826, \mathrm{p}<$ 0.001 ) transformed data from Grassy Point. The pattern of abundance was quite different at the Grand Scenic site (Fig 2C); abundances were generally low, gradually increasing from 20 September to 7 October, and then remained low and variable thereafter. There was no significant correlation between abundances at the Grand Scenic site and the other 2 sites.

\section{Otolith analysis}

Daily increment data showed that dates of otolith transitions for individuals collected from St Leonards occurred predominantly in 3 groups; approximately 19 to 24 September, 9 to 14 October and 17 to 22 October (Fig 3A). Individuals with otolith transitions between 17 and 26 September were well represented at Grassy
Point whilst a smaller number had transitions formed between 12 and 16 October (Fig. 3B). Individuals from Grand Scenic had otolith transitions formed almost entirely between 17 and 28 September (Fig. 3C).

Otolith transitions for individuals collected at St Leonards were primarily formed within the $4 \mathrm{~d}$ previous to sampling on 23 September, 14 October and 22 October (Fig. 4). Some individuals from Grassy Point and Grand Scenic also had otolith transitions formed a few days before collection, particularly in the period from 16 September to 27 September, although the majority were formed a significant time before collection (Fig. 4)

\section{Modelling}

Simulation of particle advection and dispersal with the 2-D model showed 3 major pulses in the St Leonards 'box' (Fig. 5A). A large peak in particle num-
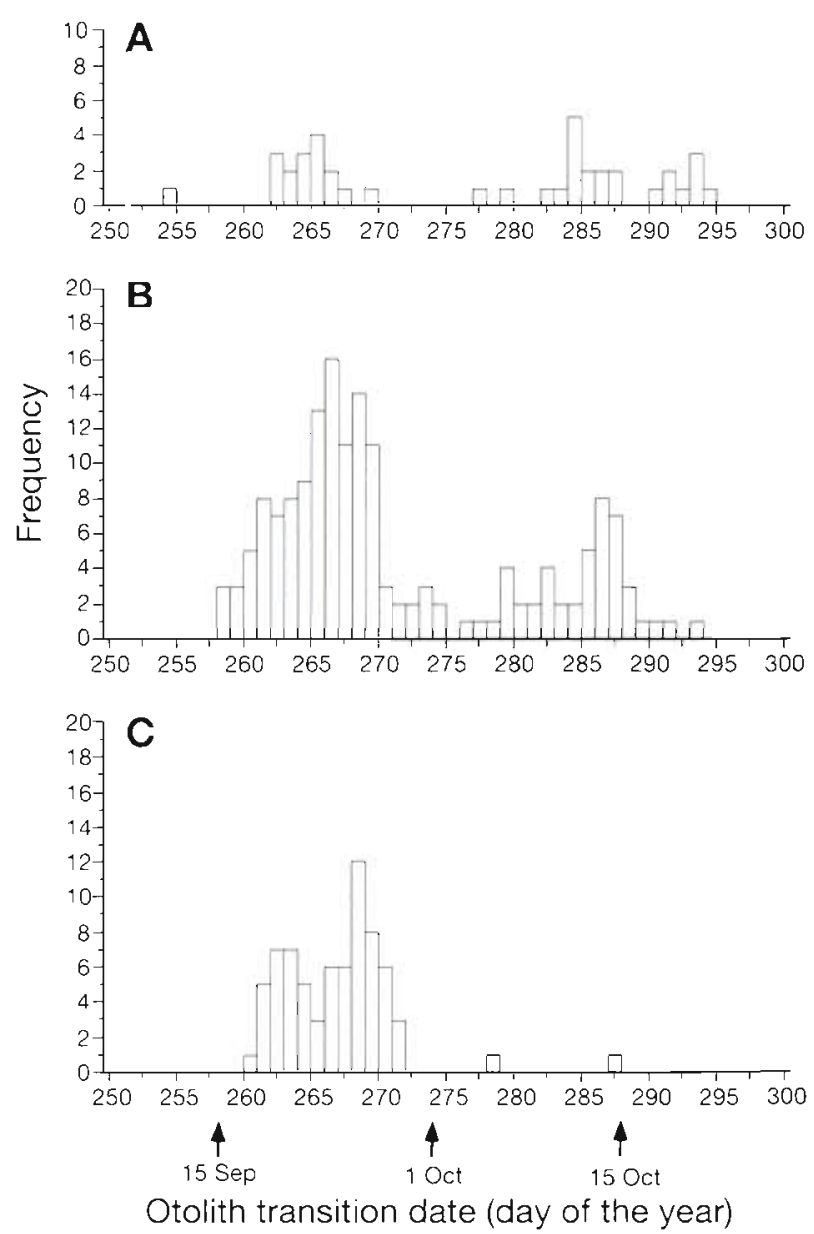

Fig. 3. Sillaginodes punctata. Frequency distribution of otolith transition dates for post-larvae collected from 3 sites around the Bellarine Peninsula pooled over sampling days. (A) St Leonards, (B) Grassy Point, (C) Grand Scenic 

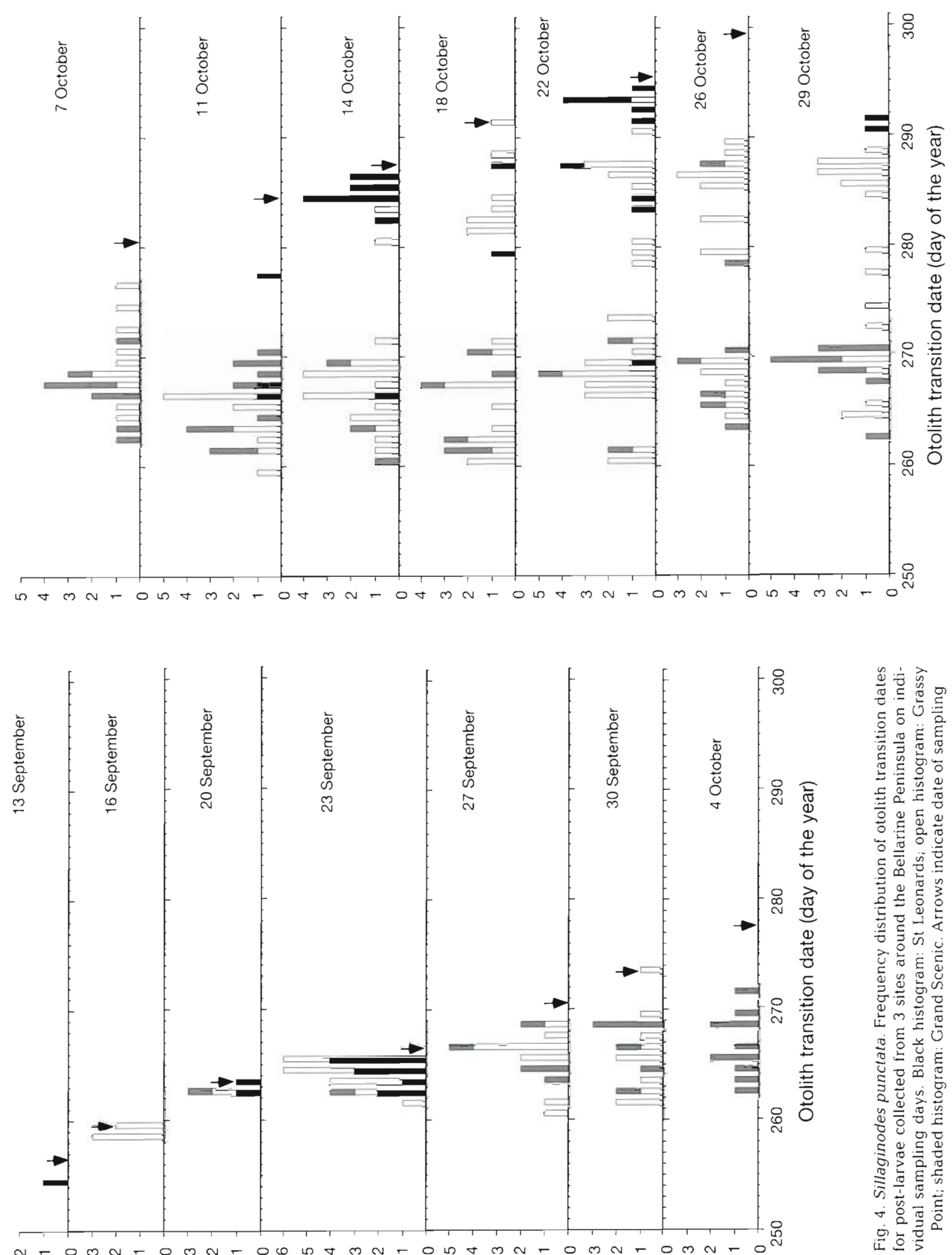

Frequency 


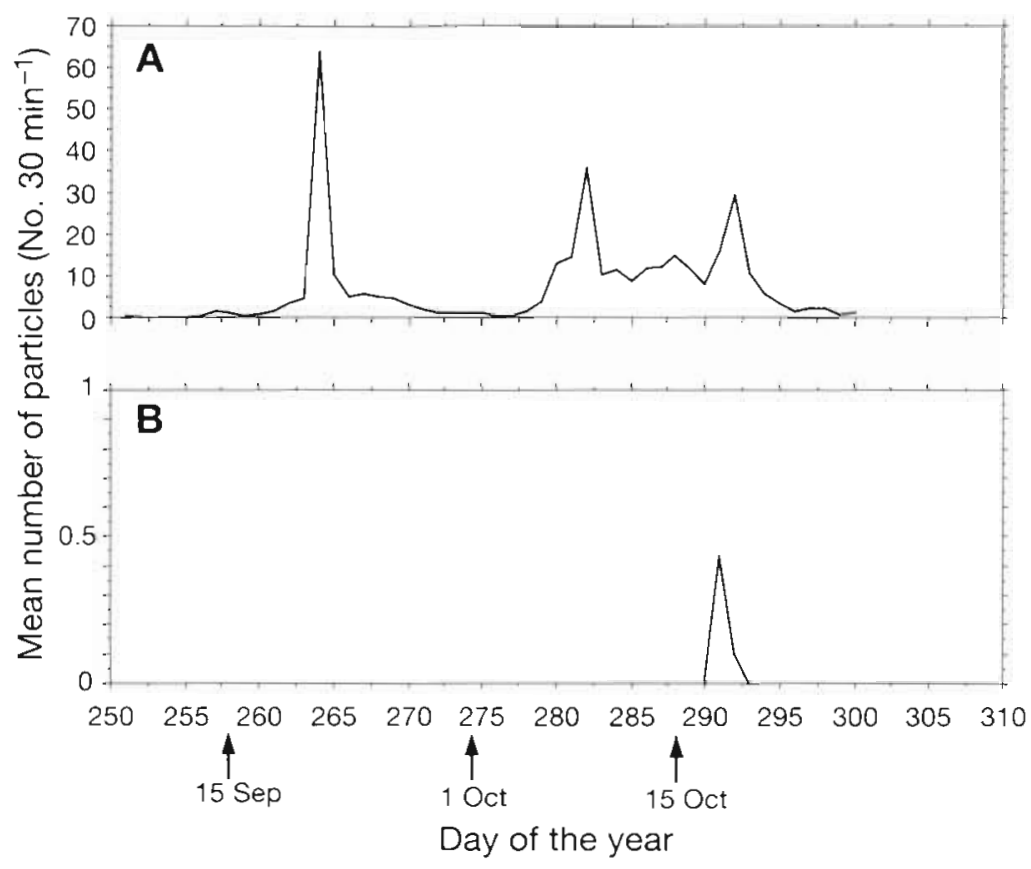

Fig. 5. Time senes of abundance of particles in model grid 'boxes' generated by a $2-D$ numerical hydrodynamic model simulation for the recruitment period. (A) St Leonards, (B) Grassy Point but relatively consistent numbers of particles from about 11 September to 6 OCtober and then a rapid rise in numbers from about 9 October with a peak around 19 to 22 October (Fig. 6B). Low numbers of particles were recorded from the Clifton Springs 'box' in pulses around 21 September, 1 and 8 October (Fig. 6C). An average of up to one particle was recorded in the Grand Scenic 'box' between 9 and 24 October (Fig. 6D).

Instantaneous spatial plots of particle distribution from the first major influx of particles (22 September) showed that particles extended to the inner edge of the Sands region in the 2-D simulation (Fig. 7A), but penetrated further into the bay in the 3-D simulation, with some particles in the Geelong Arm (Fig. 7B). Particles tended to penetrate further on the western side of the bay, and most particles were on the western side of the Sands region, in both the 2-D (Fig. 7A) and 3-D (Fig. 7B) simulations.

The plots of particle distribution inteber occurred on approximately 22 September while smaller peaks occurred around 8 and 19 October (Fig. 5A). At Grassy Point, one particle was recorded intermittently on 18 and 19 October. No particles were recorded in the Clifton Springs or Grand Scenic boxes.

The 3-D simulation again showed pulses in particle numbers at St Leonards, with a similar timing of peaks to those in the 2-D simulation. However, in this case, particles accumulated over time (Fig. 6A). The time series of particles in the Grassy Point 'box' showed low

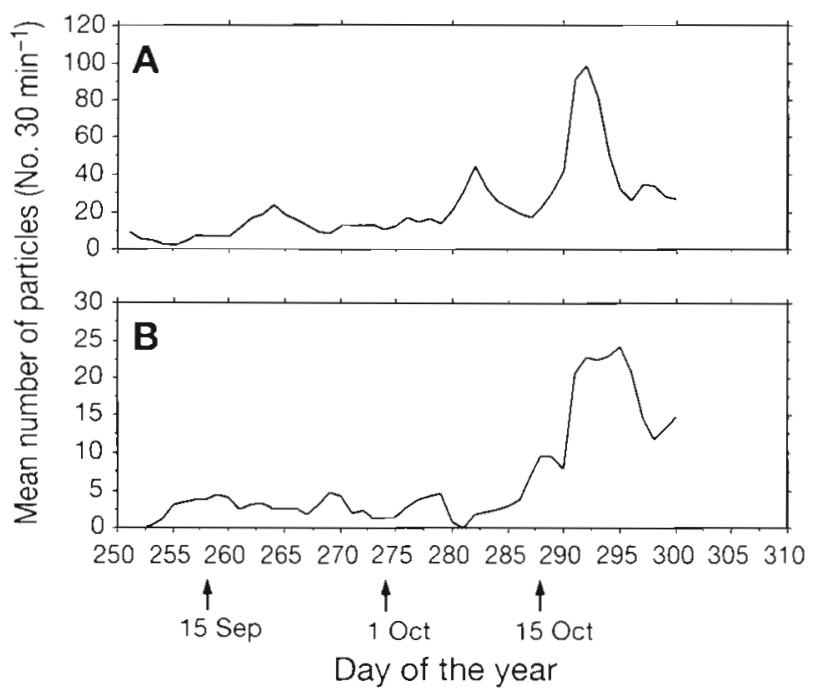
grated over the entire sampling period show that particles in the 2-D simulation were concentrated in the southern half of the bay (Fig. $7 \mathrm{C}$ ). In the 3-D simulation, particles penetrated much further into the bay, extending to the northwestern coastline (Fig. 7D). Particles were most concentrated on the western side of the bay from Port Phillip Heads to the entrance of the Geelong Arm (Fig. 7D). A few particles in the 3-D simulation extended along the full length of the Geelong Arm (Fig. 7D).
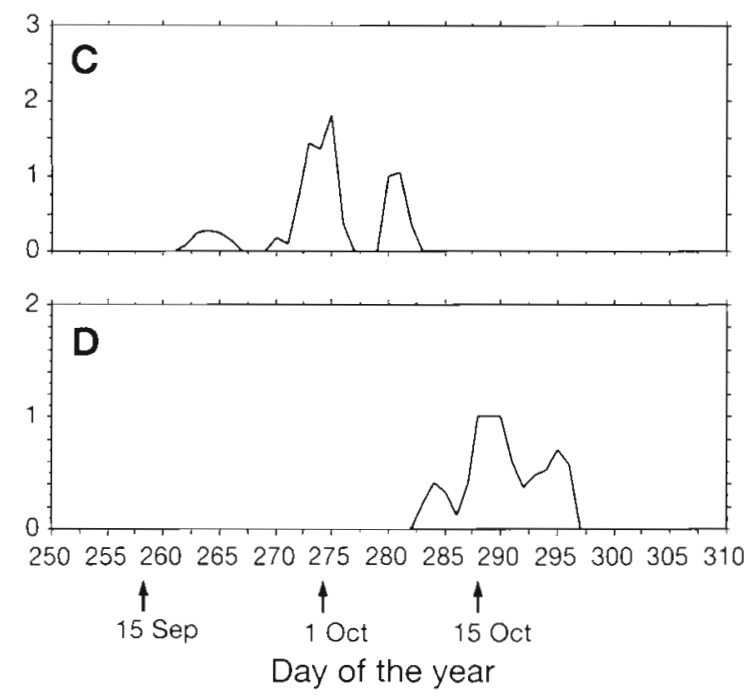

Fig. 6. Time series of abundance of particles in model grid 'boxes' generated by a 3-D numerical hydrodynamic model simulation for the recruitment period. (A) St Leonards, (B) Grassy Point, (C) Clifton Springs, (D) Grand Scenic 

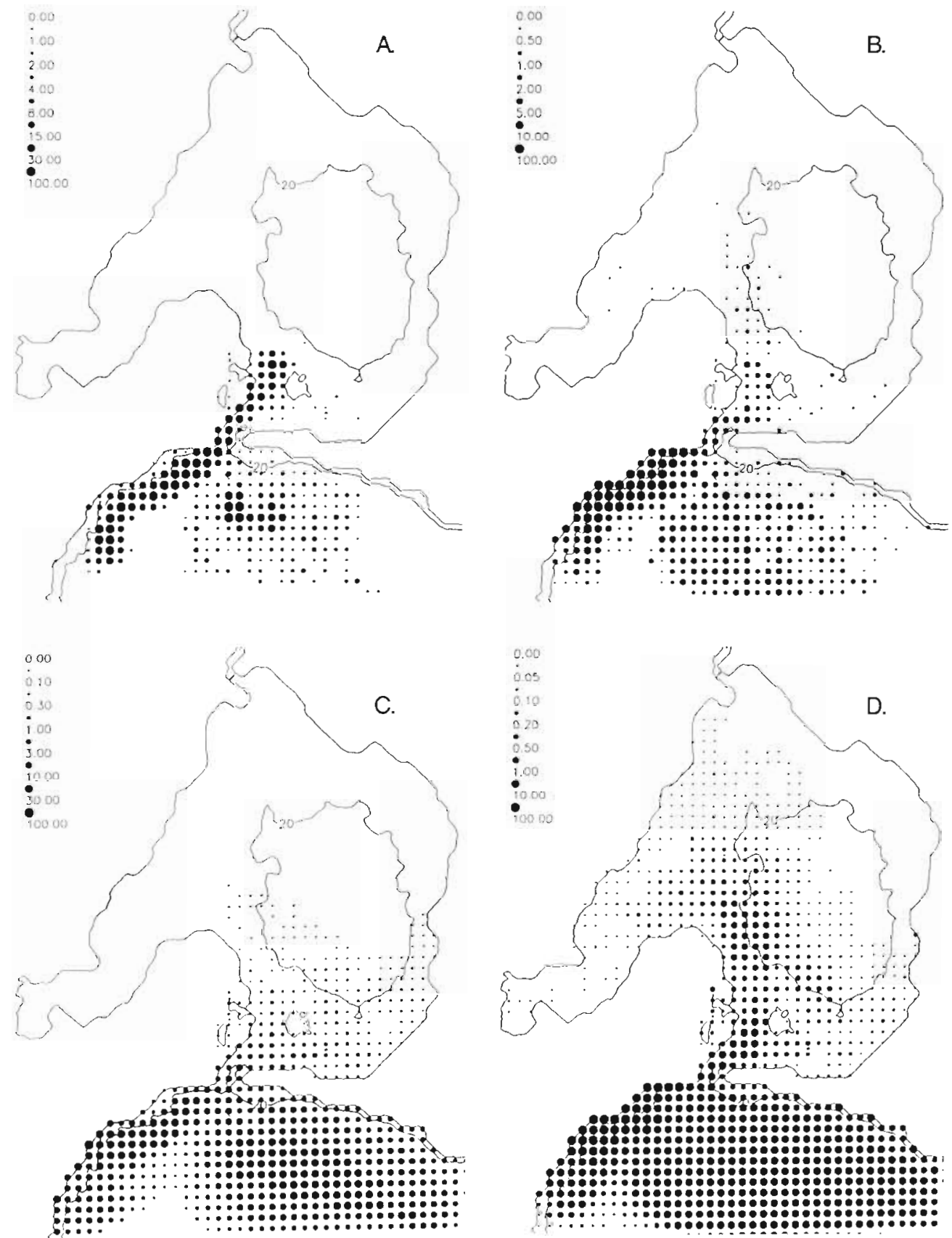

Fig. 7. Instantaneous distribution of particles in Port Phillip Bay at 06:00 h on 22 September 1993 for (A) 2-D simulation, and (B) 3-D simulation; and the integrated distribution of particles in Port Phillip Bay over the entire model run recorded at 12:00 h on 31 October 1993 for (C) 2-D simulation and (D) 3-D simulation

\section{Cross-correlation analysis}

Abundance of recruits recorded from frequent sampling at St Leonards (Fig. 2A) was compared with particle numbers in the St Leonards model 'box' (Figs. 5A $\& 6 \mathrm{~A}$ ), pooled for the equivalent ( 3 to $4 \mathrm{~d}$ ) time periods. There was a significant correlation between recruit abundances and particle numbers from the 2-D simu- lation ( $\mathrm{n}=15, \mathrm{r}=0.698, \mathrm{p}<0.001$ ), and from the $3-\mathrm{D}$ simulation when trend was removed from the model data by $\log /$ trend transforming $(n=15, r=0.615, p<$ $0.01)$, and also when both time series were differenced ( $\mathrm{n}=15, \mathrm{r}=0.609, \mathrm{p}<0.01$ ). The abundance data $r e-$ corded from frequent sampling at St Leonards was also compared with climatic variables averaged over the 3 to $4 \mathrm{~d}$ sampling intervals. A significant positive corre- 
Table 1. Correlations between physical variables and abundance of Sillaginodes punctata at St Leonards. Data were averaged over the equivalent period to recruit sampling $(\mathrm{n}=15)$

\begin{tabular}{|lcc|}
\hline Physical variable & $\mathrm{r}$ & Probability \\
\hline East-west wind vector & 0.390 & $\mathrm{~ns}$ \\
North-south wind vector & 0.248 & $\mathrm{~ns}$ \\
Wave height & -0.741 & $\mathrm{p}<0.002$ \\
Barometric pressure & 0.554 & $\mathrm{p}<0.05$ \\
\hline
\end{tabular}

lation was found between barometric pressure and abundance; however, the highest correlation was a negative relationship between wave height and abundance (Table 1). Highest abundances were related to the passage of high pressure and associated low wave conditions (Table 1, Fig. 8A).

The abundance of recruits recorded from frequent sampling at Grassy Point was compared with particle numbers in the Grassy Point model 'box', pooled for the equivalent time periods. The $2-\mathrm{D}$ simulation showed a short-lived pulse of particles (Fig. 5B), in contrast to the accumulating pattern of abundance (Fig. 2B). The abundance of recruits at Grassy Point (Fig. 2B) and the 3-D particle time series (Fig. 6B) was significantly correlated $\left(n=15, n^{*}=7, r=0.872, p<0.01\right)$. The correlation remained significant after differencing of both time series $(n=15, r=0.730, p<0.001)$. When the differenced abundance data from Grassy Point were compared with climatic variables, there was a significant

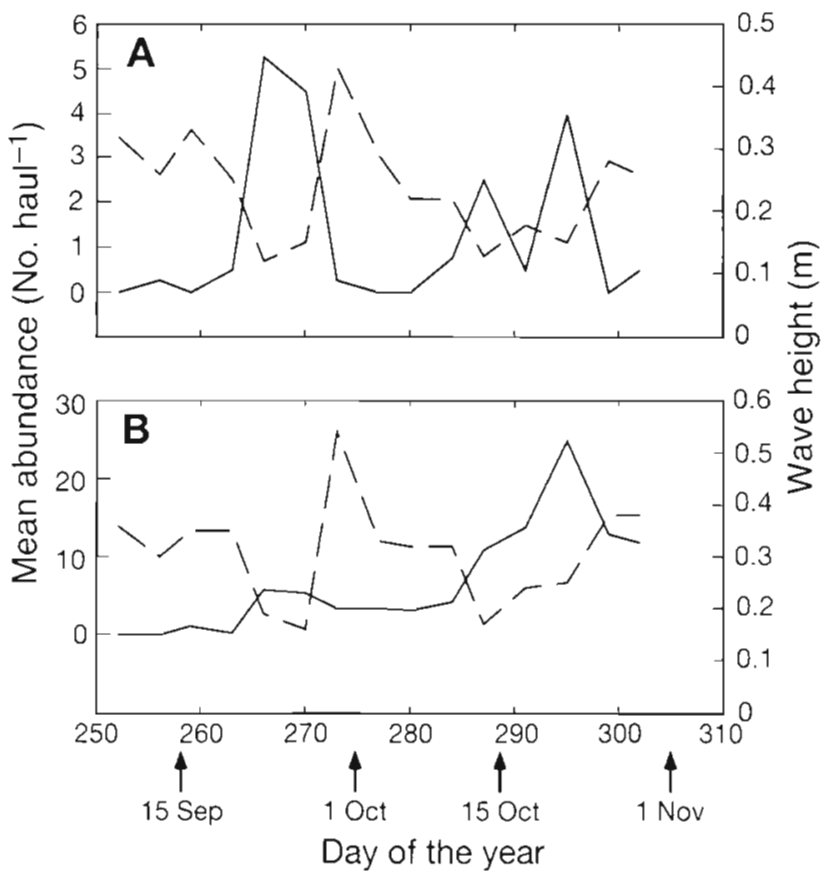

Fig. 8. Mean abundance of post-larval Sillaginodes punctata (solid line), and predicted wave heights (dashed line) averaged over equivalent time periods to recruitment sampling, at (A) St Leonards and (B) Grassy Point
Table 2. Correlations between physical variables and differenced abundance of Sillaginodes punctata at Grassy Point Data were averaged over the equivalent period to recruit sampling $(n=15)$

\begin{tabular}{|lrc|}
\hline Physical variable & $\mathrm{r}$ & Probability \\
\hline East-west wind vector & 0.245 & $\mathrm{~ns}$ \\
North-south wind vector & 0.360 & $\mathrm{~ns}$ \\
Wave height & -0.545 & $\mathrm{p}<0.05$ \\
Barometric pressure & 0.338 & $\mathrm{~ns}$ \\
\hline
\end{tabular}

negative correlation with wave height (Table 2, Fig. 8B). No significant correlations were found between physical variables and recruitment at Grand Scenic.

The relationship between recruitment and the combined influence of particle arrival, as simulated by the 3-D model, and wave height, were analysed for St Leonards and Grassy Point using multiple regression. At St Leonards, regression of abundance against log/ trend transformed model time series and wave height $\left(\mathrm{df}=2 / 12, F=11.797, \mathrm{p}<0.001, \mathrm{R}=0.81, \mathrm{R}^{2}=0.66\right)$, and differenced abundance against differenced model time series and wave height $(\mathrm{df}=2 / 11, F=11.336, \mathrm{p}<0.005$, $R=0.821, R^{2}=0.67$ ), resulted in approximately twothirds of the variance in recruit abundance being explained by the 2 variables in both cases. At Grassy Point, regression of differenced abundance against the differenced model time series and wave height $(\mathrm{df}=$ $2 / 11, F=9.905, \mathrm{p}<0.005, \mathrm{R}=0.80, \mathrm{R}^{2}=0.64$ ) also resulted in approximately two-thirds of the variance in abundance being explained by the 2 variables.

The otolith transition time series from St Leonards (Fig. 3A) showed significant correlations with the 2-D $\left(\operatorname{lag}=1, \mathrm{n}^{*}=40, \mathrm{r}=0.508, \mathrm{p}<0.001\right)($ Fig. 5A) and 3-D $\left(\operatorname{lag}=3, \mathrm{n}^{*}=17, \mathrm{r}=0.569, \mathrm{p}<0.005\right)$ (Fig. 6A) model time-series. The pattern of otolith transitions from recruits at St Leonards also showed significant correlation with some physical variables; positive correlation with westerly winds and residual sea-level, and negative correlation with barometric pressure (Table 3, Fig. 9).

Table 3. Correlations between mean daily values of physical variables and the time series of settlement estimated from otoliths of Sillaginodes punctata at St Leonards. The unadjusted $\mathrm{n}$ for each time series is 45 at zero lag. The maximum value of Pearson's correlation coefficient is given for lags between zero and $3 \mathrm{~d}$

\begin{tabular}{|lcrccc|}
\hline Physical variable & Effective n & Max & Lag & Probability \\
\hline East-west wind vector & 26 & 0.546 & 1 & $\mathrm{p}<0.005$ \\
North-south wind vector & 27 & -0.337 & 3 & $\mathrm{~ns}$ \\
Wave height & 20 & 0.438 & -1 & $\mathrm{~ns}$ \\
Residual sea-level & 17 & 0.596 & 1 & $\mathrm{p}<0.01$ \\
Barometric pressure & 17 & -0.593 & 2 & $\mathrm{p}<0.01$ \\
Tidal range & 15 & 0.434 & 1 & $\mathrm{~ns}$ \\
& & & & & \\
\hline
\end{tabular}



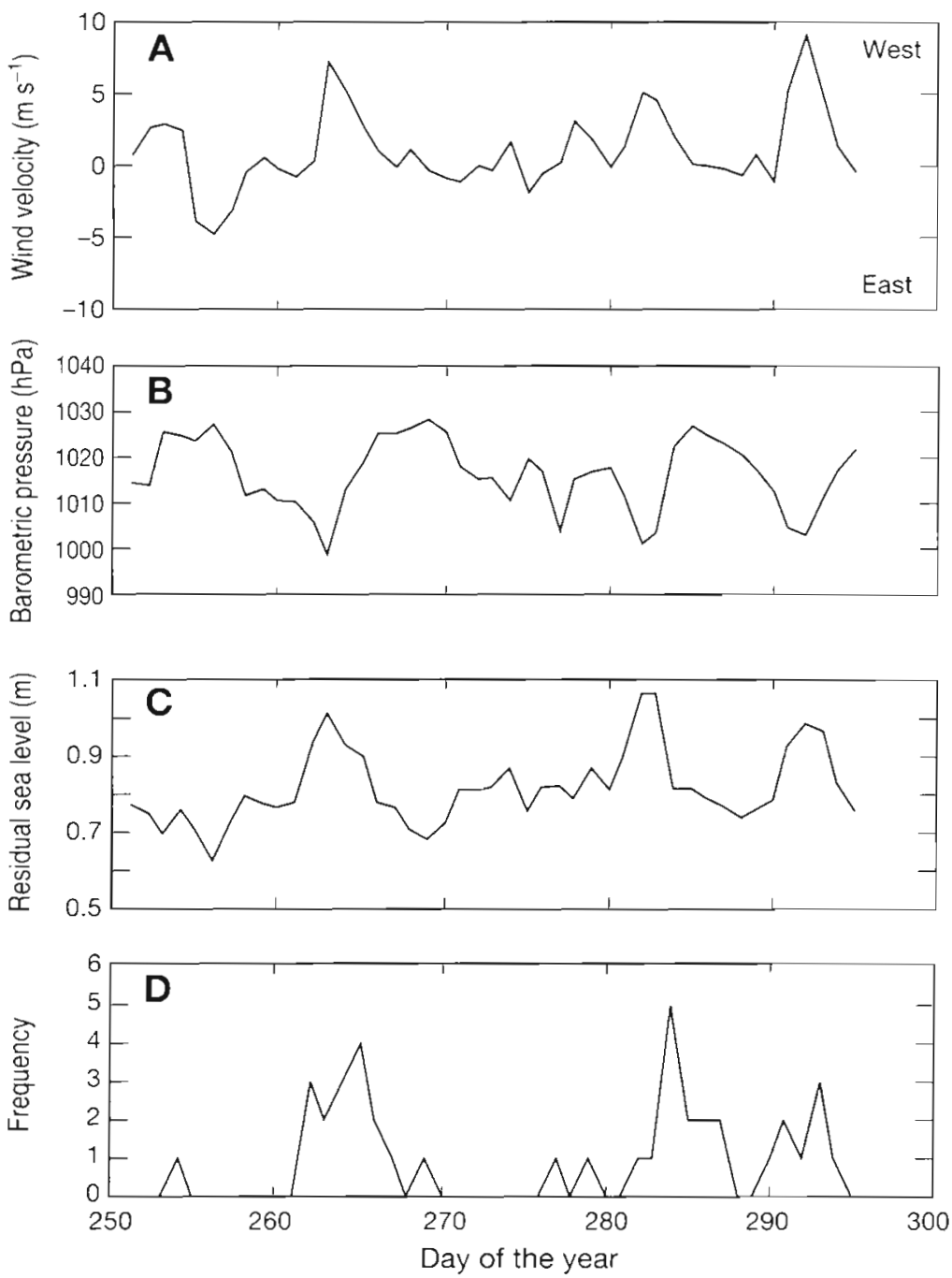

Fig. 9. Mean daily values of physical variables that were significantly correlated with post-larval Sillaginodes punctata abundance at the St Leonards site over the settlement period. (A) Magnitude of east-west wind vectors measured at Point Cook at $1 \mathrm{~h}$ intervals. (B) Barometric pressure measured at $3 \mathrm{~h}$ intervals. (C) Residual sea level (with tidal component extracted) at Point Lonsdale measured at $3 \mathrm{~h}$ intervals. (D) Frequency distribution of otolith transition dates for post-larval S. punctata collected from St Leonards

factors, the physical transport patterns in the bay and the effect of wave action on recruitment sites.

Significant correlations between recruitment data from high frequency sampling and predictions of particle numbers from 2-D and 3-D models at St Leonards, and the 3-D model at Grassy Point, are consistent with previous results from Swan Bay, where recruitment estimated from otoliths was significantly correlated with 2-D model predictions of particle numbers in Port Phillip Bay (Jenkins \& Black 1994). These results suggest that Sillaginodes punctata larvae are transported passively and that variability in larval supply results mainly from variability in physical transport processes. Jenkins \& Black (1994) suggested that the lack of influence of larval behaviour on temporal patterns of recruitment near Port Phillip Heads should not be surprising considering the strong tidal currents in the area (Black et al. 1993). However, results of the present study show a strong correlation between model simulation and recruitment at Grassy Point, where tidal currents are reduced greatly compared with the entrance (Black et al. 1993). This suggests that passive transport may be generalised over a wide range of hydrodynamic conditions experienced by this species. A caveat, however, is that the model predictions did not correlate with recruitment at the Grand Scenic site, suggesting a possible role of behaviour influencing the extreme limit of transport. However, other explanations are possible, for example, a higher resolution hydrodynamic model may be necessary to simulate transport adequately within the Geelong Arm.

\section{DISCUSSION}

Pulsed recruitment of Sillaginodes punctata at St Leonards and Grassy Point based on high frequency sampling is consistent with pulsed recruitment found in previous studies based on otolith analysis (Jenkins \& May 1994, Jenkins et al. 1996). Recruitment pulses at St Leonards were short-lived, also consistent with previous results (Jenkins et al. 1996). The timing of recruitment pulsing at Grassy Point was very similar to St Leonards, but recruits accumulated at Grassy Point. Our results show that a high proportion of the variability in recruitment at these sites can be explained by 2
The vertically averaged 2-D model was adequate for simulating Sillaginodes punctata recruitment in the tidally dominated region near Port Phillip Heads but only the 3-D model gave an adequate representation of recruitment further into the bay at Grassy Point. Three. dimensional structure would no doubt be of greater importance further into the bay where wind-driven currents would become more important than tidal currents (Black et al. 1993). Wind-induced shear in the water column is not resolved in a depth-averaged model.

We have inferred that model simulations represent larval supply to sites and therefore that recruitment is 
linked to larval supply. We did not measure larval abundances in this study; however, recent work on recruitment of Sillaginodes punctata to nearby Swan Bay has demonstrated a significant correlation between the temporal supply of larvae and the temporal pattern of recruitment (Hamer \& Jenkins 1997), supporting the important influence of larval supply on recruitment of $S$. punctata to Port Phillip Bay.

The second major factor influencing recruitment at St Leonards and Grassy Point was wave action. High postsettlement losses at sites near Port Phillip Heads has been suggested previously (Jenkins et al. 1996) although the recruitment data was of a much lower temporal resolution than the present study. The 3-D model suggested some accumulation of particles in this area but there was no accumulation of recruits. The high correlation between recruitment and wave height at St Leonards suggests that exposure to wave action may be a major factor in post-settlement losses in this area. Wave height also had a significant influence on recruitment at Grassy Point, although the association, as indicated by the correlation coefficients, was reduced compared to St Leonards. This is despite the fact that wave heights were slightly higher at Grassy Point. We suggest that the greater influence of waves at St Leonards is due to interaction with other characteristics of the area. One feature is the strong tidal currents offshore. Thus, settlers that are washed out of seagrass beds are more likely to be transported away from the site. Secondly, the shoreline at St Leonards shelves more steeply than at Grassy Point, resulting in waves breaking over seagrass beds rather than offshore. Further modelling, which resolves local currents, wave action and shoreline bathymetry at fine space scales around each of these sites, could be used to test these ideas.

Early ideas on the factors influencing the abundance of fishes in seagrass beds centred around habitat complexity and the role it played in protection from predation (Heck \& Orth 1980, Orth et al. 1984). Bell \& Westoby (1986) showed that at spatial scales greater than individual seagrass beds there was no correlation between abundances and habitat structure, leading to the hypothesis that variation in larval supply was a major factor at these scales. Our study supports previous work linking larval supply to King George whiting recruitment (Jenkins \& Black 1994, Hamer \& Jenkins 1997), but also emphasises the importance of post-settlement factors, in this case disturbance due to wave action. Given the amount of error inherent in the estimates of recruit abundance (that is, only 4 replicates every 3 to $4 \mathrm{~d}$ ) and the relative simplicity of the physical models, the amount of variation in abundance explained by these physical factors is impressive.

There is evidence that the otolith transition forms at about the time larvae enter Port Phillip Bay. Smallest recruits typically had only a few post-transition increments. Furthermore, particle entry to Port Phillip Bay predicted by 2 -D simulation and otolith transition data were significantly correlated at zero lag (Jenkins \& Black 1994). Finally, some pre-settlement larvae within the bay have post-transition increments (Hamer \& Jenkins 1997). The otolith transition may be related to changed conditions of temperature and food supply in the plankton upon entry to the bay, or to rapid settlement followed by resuspension of a proportion of larvae due to physical mixing (Jenkins et al. 1996). High frequency sampling in the present study shows that, at the St Leonards site, otolith transitions were generally formed within a few days prior to sampling, indicating that the transition is closely related to arrival of larvae to this site. The relationship between otolith transitions and the pattern of recruitment from high frequency sampling became decoupled further into the bay. Major factors influencing this relationship were the persistence of recruits at sites further into the bay. and the apparent lag between transition formation and arrival at the site, particularly at Grand Scenic, where all recruits were derived from the first cohort identified by otolith transitions. The process of resuspension by wave action and transport by currents described earlier could explain the apparent delay between arrival in the bay and recruitment to sites further in.

For the first time we have been able to identify specific climatic and hydrodynamic factors influencing the temporal pattern of recruitment of Sillaginodes punctata to Port Phillip Bay. As previously postulated (Jenkins \& Black 1994), the proximate cause of larval pulsing at the entrance to Port Phillip Bay appears to be positive anomalies in sea level, independent of tidal variation. Correlation analysis revealed that recruitment to the bay was positively related to westerly wind stress and negatively related to barometric pressure. The combined effect of strong westerly winds across Bass Strait and Coriolis forces cause the sea level to increase along the Victorian coast (Black et al. 1993). In addition, barometric pressure changes associated with the passage of weather systems induce fluctuations in sea level of approximately $1 \mathrm{~cm}$ per hPa (Black et al. 1993). In 1989, recruitment showed a cycle of approximately 7 to $14 \mathrm{~d}$ associated with the periodic passage of weather systems (Jenkins \& Black 1994). The passage of weather systems often shows deviation from a regular cycle, as was the case in the present study. Thus, apparent periodicity in recruitment data will only occur over periods of a 'stable' weather cycle. A corollary of this is that interannual variation in weather patterns, such as those induced by the El Niño southern oscillation, will lead to parallel interannual variation in the number of recruitment events (and also their magnitude and timing) 
Causes of temporal variation in recruitment of Sillaginodes punctata to Port Phillip Bay are very similar to those influencing supply of brachyuran megalopae to the east coast of the United States (Goodrich et al. 1989, Little \& Epifanio 1991). Periodic peaks in megalopae abundance were related to coastal set-up induced by wind events (Goodrich et al. 1989, Little \& Epifanio 1991). Little \& Epifanio (1991) found that longshore wind events influencing recruitment occurred on an approximate $10 \mathrm{~d}$ cycle, similar to that which can occur in the Bass Strait region (Jenkins \& Black 1994). Inshore transport of fish Iarvae associated with onshore currents produced by phenomena such as Eckman transport has been widely reported (Parrish et al. 1981, Norcross \& Shaw 1984, Boehlert \& Mundy 1987. Shenker et al. 1993, Milicich 1994).

\section{CONCLUSIONS}

This study provides a mechanism for the strong temporal variability in recruitment of Sillaginodes punctata to Port Phillip Bay. Strong westerly winds and low barometric pressure associated with the passage of weather systems produces coastal set-up and a net shoreward transport of larvae. Interannual variation in weather patterns, due to factors such as the El Niño southern oscillation, would be expected to produce interannual variation in recruitment of $S$. punctata to Port Phillip Bay. Within Port Phillip, a large proportion of the variance in recruitment to specific sites could be explained by 2 factors, physical transport patterns influencing the distribution of pre-settlement larvae, and post-settlement losses due to physical disturbance from wave action.

Acknowledgements. We thank Alistair Poore for assistance with field work. P. Hamer, G. Watson and D. Welsford provided valuable comments on the manuscript. Funding was provided by the Australian Research Council and the Fisheries Research and Development Corporation of Australia

\section{LITERATURE CITED}

Anonymous (1973) Environmental study of Port Phillip Bay: report on Phase One 1968-71. Melbourne and Metropolitan Board of Works, Melbourne

Bayley GV, Hammersley JM (1946) The 'effective' number of independent observations in an autocorrelated time series. J R Stat Soc 8:184-197

Bell JD, Westoby M (1986) Variation in seagrass height and density over a wide spatial scale: effects on common fish and decapods. J Exp Mar Biol Ecol 104:275-295

Black KP (1995) The numerical hydrodynamic model 3DD and support software. University of Waikato, Department of Earth Sciences, Occasional Report No. 19, New Zealand

Black KP (1996) Lagrangian dispersal and sediment transport model POL3DD. University of Waikato, Department of Earth Sciences, Occasional Report No. 20, New Zealand
Black KP, Gay SL, Andrews JC (1990) Residence times of neutrally-buoyant matter such as larvae, sewage or nutrients on coral reefs. Coral Reefs 9:105-114

Black K, Green M, Bell R (1996) Wave generation in three enclosed intertidal estuaries of complex shape. National Institute of Water and Atmospheric Research. Report No. NRG602/1, New Zealand

Black KP, Hatton D, Rosenberg M (1993) Locally and externally-driven dynamics of a large semi-enclosed bay in southern Australia. J Coast Res 9:509-538

Black KP, Rosenberg MA (1992) Natura] stability of beaches around a large bay. J Coast Res 8:385-397

Boehlert GW, Mundy BC (1987) Recruitment dynamics of metamorphosing English sole, Parophorys vetulus, to Yaquina Bay, Oregon. Estuar Coast Shelf Sci 25:261-281

Booth DJ (1991) The effects of sampling frequency on estimates of recruitment of the domino damselfish Dascyllus albisella Gill. J Exp Mar Biol Ecol 145:149-159

Box GEP, Jenkins GM (1986) Time series analysis, forecasting and control. Holden-Day, San Fransisco

Bruce BD (1989) Studying larval fish ecology. Benefits to King George whiting research. Safish 13:4-9

Bruce BD (1995) Larval development of King George whiting, Sillaginodes punctata, school whiting, Sillago bassensis, and yellow fin whiting, Sillago schomburgkii (Percoidei: Sillaginidae), from South Australian waters. Fish Bull US 93:27-43

Connell SD, Jones GP (1991) The influence of habitat complexity on postrecruitment processes in a temperate reef fish population. J Exp Mar Biol Ecol 151:271-294

Connolly RM (1994) Comparison of fish catches from a buoyant pop net and a beach seine net in a shallow seagrass habitat. Mar Ecol Prog Ser 109:305-309

Cowen RK (1.985) Large scale pattern of recruitment by the labrid Semicossyphus pulcher: causes and implications. J Mar Res 43:719-742

Doherty P, Fowler T (1994). An empirical test of recruitment limitation in a coral reef fish. Science 263:935-939

Farrell TM, Bracher D, Roughgarden J (1991) Cross-shelf transport causes recruitment to intertidal populations in central California. Limnol Oceanogr 36:279-288

Foreman MGG (1977) Manual for tidal heights analysis and prediction. Pacific Marine Sciences Report 77-10, Institute of Ocean Sciences, Victoria, BC

Gaines SD, Brown S, Roughgarden J (1985) Spatial variation in larval concentrations as a cause of spatial variation in settlement for the barnacle, Balanus glandula. Oecologia $67: 267-272$

Garrett C. Petrie B (1981) Dynamical aspects of the flow through the Strait of the Belle Isle. J Phys Oceanogr 11 376-393

Garrett C, Toulany B (1981) Variability of the flow through the Strait of Belle Isle. J Mar Res 39:163-189

Goodrich DM, van Montfrans J, Orth RJ (1989) Blue crab megalopal influx to Chesapeake Bay: evidence for a wind driven mechanism. Estuar Coast Shelf Sci 29:247-260

Hamer PA, Jenkins GP (1997) Larval supply and short-term recruitment of a temperate zone demersal fish, the King George whiting, Sillaginodes punctata Cuvier and Valenciennes, to an embayment in south-eastern Australia. J Exp Mar Biol Ecol 208:197-214

Hasselman K, Barnett TP, Bonws E, Carlson H, Cartwright DC, Enke K, Ewing J, Gienapp H, Hasselman DE, Kruseman P, Meerburg A, Muller P, Olbers DJ, Richter K, Sell W, Walden $H$ (1973) Measurements of wind-wave growth and swell decay during the Joint North Sea Project (JONSWAP). Deutsches Hydrographisches Institut, Hamburg 
Hasselman K, Ross DB, Muller P, Sell W (1976) A parametric wave prediction model. J Phys Oceanogr 6:200-228

Heck KL Jr, Orth RJ (1980) Seagrass habitats: the roles of habitat complexity, competition and predation in structuring associated fish and motile macroinvertebrate assemblages. In: Kennedy VS (ed) Estuarine perspectives. Academic Press, New York, p 449-464

Hixon MA, Beets JP (1993) Predation, prey refuges and the structure of coral-reef fish assemblages. Ecol Monogr 63 : $77-101$

Hughes TP (1990) Recruitment limitation, mortality, and population regulation in open systems: a case study. Ecology $71: 12-20$

Hurlbut CJ (1992) Larval release and supply predict temporal variation in settlement of a colonial ascidian. Mar Ecol Prog Ser 80:215-219

Hutchins B, Swainston R (1986) Sea fishes of southern Australıa. Swainston Publishing, Perth

Jenkins GP (1986) Composition, seasonality and distrubution of ichthyoplankton in Port Phillip Bay, Victoria. Aust J Mar Freshwat Res 37:507-520

Jenkins GP, Black KP (1994) Temporal variability in settlement of a coastal fish, the King George whiting, Sillaginodes punctata, is determined by low-frequency hydrodynamics. Limnol Oceanogr 39:1744-1754

Jenkins GP, May HMA (1994) Variation in settlement and larval duration of King George whiting, Sillaginodes punctata (Sillaginidae), in Swan Bay, Victoria, Australia. Bull Mar Sci 54:281-296

Jenkins GP, Wheatley MJ, Poore AGB. (1996) Spatial variation in recruitment, growth and feeding of post-settlement King George whiting, Sillaginodes punctata, associated with seagrass beds of Port Phillip Bay, Australia. Can J Fish Aquat Sci 53:350-359

Jessop RE (1988) The ecology of fish inhabitıng the intertidal zone of Swan Bay, Victoria, Australia. PhD Thesis, Deakin University, Victoria

Jones GP (1991) Postrecruitment processes in the ecology of coral reef fish populations: a multifactorial perspective. In: Sale PF (ed) The ecology of fishes on coral reefs. Academic Press, San Diego, p 294-328

Jones K (1980) Research on the biology of spotted (King George) whiting in South Australian waters. Safic 4: $3-7$

Levin PS (1994) Fine-scale temporal variation in recruitment of a temperate demersal fish: the importance of settlement versus post-settlement loss. Oecologia 97:124-133

Little KT, Epifanio CE (1991) Mechanism for the re-invasion

Thus article was submutted to the editor of an estuary by two species of brachyuran megalopae. Mar Ecol Prog Ser 68:235-242

Milicich MJ (1994) Dynamic coupling of reef fish replenishment and oceanographic processes. Mar Ecol Prog Ser 110:135-144

Milicich MJ, Meekan MG, Doherty PJ (1992) Larval supply: a good predictor of recruitment of three species of reef fish (Pomacentridae). Mar Ecol Prog Ser 86:153-166

Norcross BL, Shaw RF (1984) Oceanic and estuarine transport of fish eggs and larvae: a review. Trans Am. Fish Soc 113: 153-165

Orth RJ, Heck KL, van Montfrans J (1984) Faunal communities in seagrass beds: a review of the influence of plant structure and prey characteristics on predator-prey relationships. Estuaries 7:339-350

Parrish RH, Nelson CS, Bakun A (1981) Transport mechanisms and reproductive success of fishes in the Callfornia current. Biol Oceanogr 1:175-203

Raımondi PT (1990). Patterns, mechanisms, consequences of variability in settlement and recruitment of an interticial barnacle. Ecol Monogr 60:283-309

Robertson Al (1977) Ecology of juvenile King George Whiting Sillaginodes punctatus (Cuvier and Valenciennes) (Pisces: Perciformes) in Western Port, Victoria. Aust J Mar Freshwat Res 28:35-43

Sale PF, Ferrell DJ (1988) Early survivorship of juvenile coral reef fishes. Coral Reefs 7:117-124

Shenker JM, Maddox ED, Wishinski E, Pearl A, Thorrold SR, Smith N (1993) Onshore transport of settlement-stage Nassau grouper Epinephelus striatus and other fishes in Exuma Sound, Bahamas. Mar Ecol Prog Ser 98:31-43

Shore Protection Manual (1984) U.S. Army Corp of Engineers, Coastal Engineering Research Center, Vicksburg, MS

Shulman MJ, Ogden JC (1987) What controls tropical reef fish populations: recruitment or benthic mortality? An example in the Carribbean reef fish Haemulon flavolineatum. Mar Ecol Prog Ser 39:233-242

Sogard SM (1989) Colonization of artificial seagrass by fishes and decapod crustaceans: importance of proximity to natural eelgrass. J Exp Mar Biol Ecol 133:15-37

Thorrold SR, Shenker JM, Maddox ED, Mojica R, Wishinski E (1994) Larval supply of shorefishes to nursery habitats around Lee Stockıng Island, Bahamas. Il. Lunar and oceanographic influences. Mar Biol 118:567-578

Underwood AJ, Fairweather PG (1989) Supply-side ecology and benthic marine assemblages. TREE 4:16-21

Wilkinson L, Hill M, Vang E (1992). SYSTAT: statistics, version 5.2 edn. SYSTAT Inc, Evanston, IL

Manuscript first received: July 25, 1996

Revised version accepted: December 23, 1996 